\title{
Yksityisyyden viestinnällinen säätely ja kuunteleminen nuorten aikuisten matkapuhelinkeskusteluissa
}

\author{
Tuula-Riitta Välikoski \& Nina Lindberg
}

\section{Tiivistelmä}

Tämä kvantitatiivinen tutkimus kartoittaa nuorten aikuisten opiskelijoiden käsityksiä siitä, miten he säätelevät yksityisistä asioista kertomistaan, kuuntelevat matkapuhelinkeskusteluissaan ja miten tulokset eroavat sukupuolittain. Kartoitukset tehtiin samalla kyselylomakkeella ${ }^{1}$, mutta eri henkilöille vuonna 2007 $(\mathrm{n}=216)$ ja vuonna $2010(\mathrm{n}=289)$ Tampereen ja Jyväskylän yliopistoissa. Kuunteleminen on monitahoinen kognitiivinen prosessi, jonka tuloksena reagoidaan sosiaalisessa suhteessa puheviestinnän keinoin (Brownell 1990). Tarkkaavaisuus ja huomion kiinnittäminen käynnistävät kuuntelemisen (Imhof 2003), ja sanomaan keskittyminen ja läsnäolon osoittaminen ovat merkkejä kuuntelemisesta (Brownell 2002; Flynn, Välikoski \& Grau 2008).

Nuoret aikuiset kuuntelevat matkapuhelinkeskusteluissaan holistisesti, he vaikuttavat keskittyvän sanomaan ja olevan läsnä keskustelusuhteessa. He eivät häiriinny ympärillä käytävistä muista keskusteluista, joskin he ovat varsin tietoisia ympäristöstään. Kuuntelemista ei koettu helpoksi eikä matkapuhelinkeskusteluja käytäisi, jos kasvokkainen keskusteluyhteys olisi mahdollinen.

Matkapuhelinkeskustelun paikka vaikuttaa keskustelunaiheisiin. Vältettäviä aiheita kontrolloitiin ilmoittamalla, että ei voi puhua aiheesta, että palaa aiheeseen myöhemmin tai että siirtyy puhumaan rauhallisempaan paikkaan. Vastaajajoukon mielestä matkapuhelinkeskusteluille sopimattomat paikat, kuten oppitunnit, elokuvat ja uskonnolliset toimitukset, kontrolloivat aiheita automaattisesti.

Tulokset olivat molempina tutkimusvuosina hyvin pysyviä, eroja oli vähän eikä sukupuoli taustoittanut valintoja. Tulokset myös osoittivat kuuntelemisen olevan keskeinen tekijä matkapuhelinkeskusteluissa. Samoin vaikka matkapuhelinkeskustelut eroavat kasvokkain keskusteluista, myös niissä vahvistuivat Petronion (2002) yksityisten asioiden viestinnällisen säätelyn periaatteet.

Asiasanat: kuunteleminen, matkapuhelinkeskustelut, nuoret aikuiset, yksityisyyden viestinnällinen säätely 


\section{Johdanto}

Itsestä kertominen on tärkeimpiä ihmisenä olemisen viestintätilanteita. Itseä koskevia yksityisiä asioita ei kuitenkaan kerrota kaikille. Avrami ym. (2007) ovat todenneet, että ihmiset tasapainoilevat itsestä kertomisen ja yksityisten asioiden itsellään pitämisen välillä kaikissa keskusteluissa. Kyseistä ilmiötä taustoittaa yksityisyyden viestinnällisen säätelyn teoria, joka sisältää viisi toiminnallista periaatetta (Petronio 2007, 219): ihmiset uskovat yksityisten asioidensa kuuluvan vain heille itselleen (1), ihmisillä on oikeus valita, kenelle he näistä asioista kertovat (2) ja ihmiset kehittävät erilaisia sääntöjä yksityisyydestä kertomiseensa (3). Mikäli yksityisiä asioita jaetaan jonkun kanssa jaetaan, oletetaan, että tuo toinen myös säätelee niistä kertomistaan (4), ja jos yksityisyydestä kertomisen säännöt ovat uhattuna, syntyy keskustelijoiden välille erilaisia jännitteitä (5). Sen, mikä on kullekin ihmiselle yksityistä, päättää ihminen itse. Samoin tähän päätökseen kuuluu tieto siitä, kenelle yksityisistä asioista kerrotaan ja miten yksityistä tietoa muilta suojataan. Suojaus tapahtuu yleensä kolmella tavalla: kehitetään sääntöjä siitä, missä tilanteessa ja milloin yksityisistä asioista kerrotaan ja mitä tapahtuu, jos luottamus keskustelukumppanin kanssa häiriintyy (vrt. Metzger 2005).

Yksityisyyden viestinnällinen säätely pohjautuu alun perin sosiaalisen läpäisyn teoriaan (Altman \& Taylor 1973), jossa keskeinen käsite on itsestä kertominen. Itsestä kertominen on Jourardin (1968) mukaan sellaisten asioiden kertomista, joita keskustelukumppanit eivät saisi toisistaan muuten helposti selville. Kertominen on myös puhujan vapaaehtoista ja intentionaalista puhetta henkilökohtaisista asioista sosiaalisessa vuorovaikutuksessa (Papini \& Farmer 1990). Päätös siitä, mikä on kertomistilanteessa kullekin ihmiselle henkilökohtaista ja yksityistä, on kertojan itsensä.

Sekä itsestä kertominen että yksityisiksi koetut asiat eroavat sukupuolittain (mm. Kacchi \& Link 2009; Wilkins \& Gareis 2006). Naiset näyttävät kertovan enemmän tunteisiin liittyvistä asioista kuin miehet. Miehet taas välttävät esimerkiksi sellaisten asioiden kertomista itsestään, jotka asettavat heidän toimintansa kyseenalaiseksi. (Wood 2002, 122-124.)

Yksityisyyden viestinnällisessä säätelyssä on myös kulttuurisia eroja (Wilkins \& Gareis 2006; Wilkins \& Isotalus 2009). Vaikka mikään viestintäkulttuuri ei ole pysyvä, vaan sitä edustavien ihmisten vuorovaikutuksen aikaansaama ja jatkuvasti muuttuva, useassa kulttuurissa on nähty toistuvia, juuri kyseiseen kulttuuriin kuuluvia viestinnällisiä piirteitä. Suomalaista viestintä-

1 Tutkimuksessa käytetty kyselylomake on sama ja vuoden 2007 aineisto on sama kuin tutkimuksessa Välikoski, T-R., Imhof, M. Worthington, D., Fitch-Houser, M. \& Kim, S. 2008. Mobile telephony, listening and privacy management: a cross cultural comparison between Finnish, German, Korean and US-American university students. Tutkimus on esitetty European Communication Research and Education Association, ECREAn konferenssissa Barcelonassa, 25-28.11.2008. 
kulttuuria kuvataan esimerkiksi sanallisen viestin kirjaimellisuutta korostavaksi (Kirra 2000) ja ihmisten yksityisyyttä painottavaksi (Wilkins \& Isotalus 2009, 9). Sekä toisten että oman yksityisyyden voidaan nähdä havainnollistuvan toisen puheen kunniottamisena siten, että puhujaa ei juuri keskeytetä (Wilkins \& Isotalus 2009, 4), kuuntelijan roolissa on helppo olla (Välikoski ym. 2005, 94) ja avautuminen henkilökohtaisista asioista tapahtuu lähinnä perhe- ja ystävyyssuhteissa (Carbaugh, Berry \& Nurmikari-Berry 2006; Virtanen 2009). Itsestä kertominen rakentaa myös puhujan viestijäkuvaa, josta suomalaiset ovat tutkitusti huolissaan. Viestijäkuvaan kuuluu lisäksi puhumistilanteen ja yleisön tarkkailu (vrt. Wilkins \& Isotalus 2009).

Nykyiseen suomalaiseen viestintäkulttuuriin kuuluvat kiinteästi keskustelut matkapuhelimien välityksellä, sillä maa on ollut yksi matkapuhelimien tuotekehittelymaa jo pitkään (Castells \& Himanen 2002). Matkapuhelimissa yksityisistä asioista kertominen on haasteellisempaa kuin kasvokkainkeskusteluissa, sillä kuulijana voi varsinaisen keskustelukumppanin lisäksi olla myös niitä, joille keskustelun aihetta ei haluta tarjoilla. Nämä kuulijat voivat olla myös vaivautuneita kuullessaan mainittuja asioita, kuten Rainie \& Keeter (2006) ovat todenneet. Heidän mukaansa yli 82 prosenttia yhdysvaltalaisista kyseiseen tutkimukseen vastanneista ilmoitti olleensa kiusaantuneita ainakin joskus jouduttuaan kuuntelemaan henkilökohtaisia matkapuhelinkeskusteluja julkisilla paikoilla. Matkapuhelinkesteluissa kehittyy myös tila, jota kutsutaan läsnä olemattomaksi läsnäoloksi (absent presence). Tällä tarkoitetaan tilaa, jossa keskustelija on suorassa viestintäsuhteessa puhelimitse keskustelukumppaninsa kanssa, vaikka hänen ympärillään fyysisesti on muita potentiaalisia viestintäkumppaneita, joiden kanssa hän on olematta läsnä (Gergen 2002).

Matkapuhelimitse on useita mahdollisuuksia yhteydenpitoon, mutta puhuminen ja kuunteleminen on edelleen keskeistä. On todettu, että matkapuhelinkeskustelut voivat lujittaa keskustelijoiden välistä kanssakäymistä jopa enemmän kuin kasvokkain tapahtuvissa keskusteluissa, koska niissä on keskityttävä sanomaan ja yritettävä kuunnella ilman visuaalisia vihjeitä sanomasta (Kim ym. 2007). Kuunteleminen on monitahoinen kognitiivinen prosessi, jossa kuulemisen, ymmärtämisen, muistin ja tulkinnan tuloksena reagoidaan sosiaalisessa suhteessa puheviestinnän keinoin (Brownell 1990). Tarkkaavaisuus ja huomion kiinnittäminen käynnistävät kuuntelemisen (Imhof 2003). Tieto sukupuolten välisistä kuuntelemisen eroista on vielä niukkaa, mutta naisten on todettu kiinnittävän huomiota ja tarkkailevan kuuntelussaan eri asioita kuin miehet. Naiset etsivät kuullusta sanallisen informaation lisäksi myös affektiivisia vihjeitä enemmän kuin miehet, jotka puolestaan tarkastelevat selvästi erikseen emootiot sanamerkityksistä (Marsnik 1993, 34; Schirmer \& Kotz 2002, teoksessa Waaramaa-Mäki-Kulmala 2009, 75). Sanomaan keskittyminen ja läsnäolon osoittaminen vuorovaikutussuhteessa ovat kuuntelemisen viestinnällistä ydintä ( $\mathrm{mm}$. Brownell 2002; Flynn, Välikoski \& Grau 2008). Jos itsestä kertominen on puhu- 
jalle tärkeää oman sanoman tuottamista, on sanoman vastaanottaminen ja siihen regointi eli kuunteleminen, toimivan vuorovaikutuksen perusta.

Matkapuhelinkeskustelut eroavat kasvokkain tapahtuvasta vuorovaikutuksesta, mutta näyttää siltä, että itsestä kertomiseen ja kuuntelemiseen liittyvät tekijät ovat keskeisiä myös matkapuhelimitse käytävissä keskusteluissa (Avrami ym. 2007; Katz 2007).

Tässä artikkelissa esitellään tutkimus, jonka tavoitteena on kartoittaa nuorten aikuisten käsityksiä siitä, kuinka yksityisten asioiden kertomista säännellään viestinnällisesti matkapuhelinkeskusteluissa ja kuinka matkapuhelinkeskusteluissa kuunnellaan. Koska kyseiset viestinnälliset teot ovat tyypillisiä myös suomalaisille viestintäkulttuurille, taustoitetaan tuloksia artikkelissa myös sen perusteella. Tutkimuksen tavoitetta selvitetään siten, että yksityisyyden viestinnällistä säätelyä lähestytään Petronion (2002) esittämän käsityksen ja kuuntelemista Imhofin (2003), Brownellin (2002) ja Flynn, Välikoski \& Graun (2008) käsitysten mukaan, joiden perusteella on luotu kolme tutkimuskysymystä:

Miten nuoret aikuiset ilmentävät käsityksensä mukaan matkapuhelinkeskusteluissa

1. yksityisyyden viestinnällistä säätelyä (mistä aiheesta puhutaan, missä ympäristössä, milloin ja mitä tehdään, jos aiheesta ei halua puhua)?

2. kuuntelemista (huomion kiinnittäminen, tarkkaavaisuus, keskittyminen, läsnäolo)? Lisäksi haluttiin selvittää,

3. onko yksityisyyden viestinnällisen säätelemisen ja kuuntelemisen ilmenemisessä matkapuhelinkeskusteluissa sukupuoleen perustuvia eroja?

Kartoitus on tehty vuonna 2007 ja 2010 samalla kyselylomakkeella eri henkilöille. Tällä menettelyllä selvitettiin tulosten pysyvyyttä.

\section{Tutkimuksen toteutus}

Nuoriksi aikuisiksi valikoitui opiskelijajoukko Tampereen ja Jyväskylän yliopistoissa. Tutkimus muodostui kyselystä, joka tehtiin ensimmäisen kerran vuonna 2007 (yhteensä 216 opiskelijaa) ja toisen kerran samalla kyselylomakkeella vuonna 2010 (yhteensä 289 opiskelijaa). Osallistujat olivat noin 26-vuotiaita $(\mathrm{M}=25,6 ; \mathrm{SD}=6,4)$ vuonna 2007 ja 24-vuotiaita $(\mathrm{M}=24,2 ; \mathrm{SD}=4,7)$ vuonna 2010. Naisia osallistujista oli yli puolet molempina vuosina. Opiskelijoiden pääaineet vaihtelivat suuresti (ks. taulukko 1).

Kysely toteutettiin paperikyselynä eri kurssikokoontumisten alussa kahdessa yliopistossa. Osallistujille kerrottiin suullisesti lyhyesti, että kyselyssä kartoitetaan matkapuhelimen käyttöä, käytävien keskustelujen luonnetta sekä kuuntelemista. Näin tuttujen ja todennäköisesti helposti vastattavien ja vastaajan taustoihin liittyvien kysymysten jälkeen lähestyttiin varsinaisen tutkimuksen 
Taulukko 1. Nuorten aikuisten taustatiedot tutkimusvuosina

\begin{tabular}{|c|c|c|}
\hline & $2007(N=216)$ & $2010(N=289)$ \\
\hline $\begin{array}{l}\text { Ikä } \\
\text { keskiarvo (M) } \\
\text { keskihajonta (SD) }\end{array}$ & $\begin{array}{r}25,64 \\
6,44\end{array}$ & $\begin{array}{r}24,24 \\
4,67\end{array}$ \\
\hline $\begin{array}{l}\text { Sukupuoli } \\
\text { mies } \\
\text { nainen }\end{array}$ & $\begin{array}{c}78 \\
132 \\
\end{array}$ & $\begin{array}{l}122 \\
166\end{array}$ \\
\hline $\begin{array}{l}\text { Opintovuosi } \\
\text { 1. vuosi } \\
\text { 2. vuosi } \\
\text { 3. vuosi } \\
\text { 4. vuosi tai } \\
\text { enemmän }\end{array}$ & $\begin{array}{l}55 \\
31 \\
50 \\
79\end{array}$ & $\begin{array}{l}51 \\
67 \\
75 \\
93\end{array}$ \\
\hline $\begin{array}{l}\text { Kolme yleisintä } \\
\text { pääaineluokkaa }\end{array}$ & $\begin{array}{l}\text { Sosiaalitieteet } \\
\text { (ja historia) }(n=99) \\
\text { Tietokoneet/Informaa- } \\
\text { tioteknologia }(n=42) \\
\text { Kielet ja kirjallisuus } \\
(n=32)\end{array}$ & $\begin{array}{l}\text { Kaupalliset ja } \\
\text { hallinnolliset }(n=89) \\
\text { Tietokoneet/Informaatio- } \\
\text { teknologia }(n=78) \\
\text { Viestintä/Journalismi/ } \\
\text { Logopedia/Media }(n=38)\end{array}$ \\
\hline
\end{tabular}

Taustatietoihin vastaamisessa oli myös puuttuvia havaintoja.

kysymyksiä. Yksityisyyden viestinnällistä säätelyä kartoitettiin kysymyksilla, kuten mistä aiheista on sopivaa tai sopimatonta keskustella minkäkinlaisissa paikoissa, mitä aiheita vältetään, oliko keskustelija joutunut noloihin tilanteisiin puhelimen soidessa ja mitä keskustelija tekee, jos hän ei halua kertoa asioistaan julkisilla paikoilla. Kuuntelemista puolestaan kartoitettiin väittämällä kuuntelemisen helppoudesta, kysymyksillä siitä, millaisiin asioihin kiinnitetään omassa puhelinkeskustelussa huomiota ja miten keskustelija keskittyy sekä omaan puheluunsa että kuuntelemaan muuta keskustelua tai muita puheluita oman puhelunsa ympärillä.

Kyselyyn vastaaminen kesti molemmilla kerroilla noin 20 minuuttia. Enemmistö lomakkeen osioista sisälsi nominaaliasteikollisia vaihtoehtoja (esimerkiksi tyyliin sopiva/ei sopiva), mutta mukana oli myös Likert-tyyppisiä vaihtoehtoja (esimerkiksi ei koskaan - aina). Avoimia kysymyksiä oli vain yksi dikotomisen kyllä-ei-vaihtoehdon täydentäjänä kysymyksessä: Oletko joutunut noloihin tilanteisiin puhelimesi soidessa? Jos olet, niin kerro millaisiin. Kuvauksia avoimeen kysymykseen tuli molempina vuosina erittäin niukasti, joten kohta poistettiin lopullisesta analyysista.

Kyselyn strukturoitujen kysymysten vastaukset syötettiin SPSS for Windows -tilastointiohjelmaan (versio 16). Samaa ohjelmaa käytettiin myös analyysien tekemiseen. Koska kysymykset antoivat puhtaasti kvantitatiivista dataa, niiden prosenttijakaumat ja merkitsevyydet oli mahdollista selvittää. Tar- 
vittavat taulukot luotiin tilastointiohjelman avulla. Ennen kuin tuloksia päästiin analysoimaan, jokaisesta muuttujasta tehtiin frekvenssitaulukot. Täten saatiin tarkastettua, että tilastointiohjelmaan syötetyt tiedot olivat oikein ja saatiin myös tietoa vastausten jakaantumisesta tulevia testejä ajatellen.

Tämän tutkimuksen kannalta keskeisiä olivat muuttujien keskiarvot ja keskihajonnat. Muuttujien riippuvuuden ja tilastollisen merkitsevyyden testaamiseen käytettiin joko t-testiä tai khiin neliö -testiä. T-testiä käytettiin kahden muuttujan keskiarvoja testattaessa. Khiin neliö -testiä sovellettiin, kun muuttujia oli useampia ja kun haluttiin saada selville, oliko vastausten jakauma jotain muuta kuin ennaltaodotettu.

\section{Tulokset}

Matkapuhelimia oli ollut vastaajilla melkein puolet ikävuosistaan eli vuonna 2007 lähes 10 vuotta $(\mathrm{M}=9,63 ; \mathrm{SD}=2,34)$ ja vuonna 2010 melkein 11 vuotta $(\mathrm{M}=10,40 ; \mathrm{SD}=2,12)(\mathrm{t}(341,70)=2,02 ; \mathrm{p}<.05)$. Puhelinta käytettiin pääsääntöisesti sen helppokäyttöisyyden ja teknisen kätevyyden takia. Vuonna 2007 aikaa puhelinkeskusteluihin käytettiin hiukan yli tunti ja vuonna 2010 selvästi yli tunti päivittäin keskimäärin $(\mathrm{t}(492)=-.74 ; \mathrm{p}=.46$. $\left.\chi^{2}(1, n=505)=2,12 ; \mathrm{p}=.15\right)$. Puhelimen käytön pääsyy näyttäisi edelleen olevan perheen ja ystävien välinen yhteydenpito, mutta myös työasioiden hoitaminen. Vaikka vastaajajoukko koostui opiskelijoista, varsin suuri joukko heistä ilmoitti käyttävänsä matkapuhelintaan myös työasioihin. Luvut kahtena tutkimusvuotena olivat lähes identtiset.

Vastaajilla oli matkapuhelin mukanaan aina tai hyvin usein. Tämä tieto saatiin kysymällä asiaa Likert-asteikon vaihtoehdoilla (1) ei koskaan sekä (6) aina mukana. Suurin osa vastaajista ilmoitti molempina vuosina pitävänsä puhelintaan aina mukanaan. Sukupuolten välillä ei ollut eroa puhelimen käytössä tutkimusvuosina. Yleisimmin matkapuhelinkeskusteluja käydään töissä, ostoksilla ja ajettaessa autoa. Tätä asiaa kysyttiin nuorilta aikuisilta sekä vuonna 2007 että 2010. Mitattaessa asiaa kuusiportaisella Likert-asteikolla ( 1 = ei koskaan; 6 = aina) selvisi, että tutkittu ryhmä puhuu molempina vuosina mainituissa paikoissa matkapuhelimeen varsin harvoin, mutta erityisen vähän autolla ajaessaan $(\mathrm{M}=2,18 ; \mathrm{SD}=1,13$, vuonna 2007 ja $\mathrm{M}=2,25 ; \mathrm{SD}=1.13$ vuonna 2010) $(\mathrm{t}(502)=-, 76 ; \mathrm{p}=.45)$ verrattaessa ostoksilla käyntiin tai työskentelyyn.

\section{Yksityisyyden viestinnällinen säätely}

Eroja löytyi nuorten aikuisten käsityksistä paikoista, joissa oli sopivaa tai sopimatonta käydä matkapuhelinkeskusteluja. Kuten taulukosta 2 käy ilmi, khii toiseen -testit osoittivat melkein tilastolliset erot kaikissa listatuissa keskustelupaikoissa. Erityisen selkeät tilastollisesti merkitsevät erot olivat luentojen tai 
oppituntien ja elokuvien aikana käytävissä matkapuhelinkeskusteluissa eli niitä pidettiin sopimattomina selvästi aiempaa enemmän. Muuten edelleen vuonna 2010 oli sopimatonta puhua teatterissa, konserteissa ja uskonnollisessa toimituksessa. Sen sijaan ravintoloissa ja päivällisseurueessa puhelimeen puhuminen riippui vuosina 2007 ja 2010 lähes identtisesti tilanteesta, ja tätä mieltä olivat sekä naiset että miehet. Vuonna 2010 päivällisseurassa puhumista naiset tosin pitivät hiukan sopimattomampana kuin miehet. Bileissä taas oli vuonna 2010 aiempaa sopivampaa käydä matkapuhelinkeskusteluja, ja näin ajattelivat erityisesti miehet. Samana vuonna miehet katsoivat julkisissa WCissä käytävät puhelinkeskustelut sopivammaksi kuin vuonna 2007 (taulukko 2).

Taulukko 2. Frekvenssitaulukko sopivista ja sopimattomista paikoista matkapuhelinkeskusteluille tutkimusvuosina sukupuolen mukaan

\begin{tabular}{|c|c|c|c|c|c|c|c|c|c|c|c|c|}
\hline \multirow[t]{3}{*}{ Paikka } & \multicolumn{4}{|c|}{ Sopimaton } & \multicolumn{4}{|c|}{ Sopiva } & \multicolumn{4}{|c|}{ Riippuu } \\
\hline & \multicolumn{2}{|c|}{2007} & \multicolumn{2}{|c|}{2010} & \multicolumn{2}{|c|}{2007} & \multicolumn{2}{|c|}{2010} & \multicolumn{2}{|c|}{2007} & \multicolumn{2}{|c|}{2010} \\
\hline & nainen & mies & nainen & mies & nainer & mies & nainen & mies & nainen & mies & nainen & mies \\
\hline ravi & 22 & 11 & 42 & 21 & 18 & 21 & 12 & 15 & 91 & 47 & 112 & 86 \\
\hline luent & 123 & 76 & 162 & 119 & 6 & & & & 2 & 2 & 2 & \\
\hline elokı & 22 & 78 & 6 & 122 & 6 & 0 & 0 & 0 & 2 & 1 & 0 & 0 \\
\hline & 39 & 23 & 65 & 37 & 11 & 14 & 6 & 17 & 79 & 42 & 95 & 6 \\
\hline bilee & 1 & & 2 & 4 & 100 & 57 & 117 & 103 & 29 & 21 & 47 & 15 \\
\hline usko & 27 & 68 & 157 & 109 & 2 & 4 & 1 & 0 & 2 & 7 & 7 & $r$ \\
\hline Ilkinen WC & 15 & 16 & 21 & 19 & 59 & 37 & 56 & 61 & 57 & 26 & 81 & 42 \\
\hline
\end{tabular}

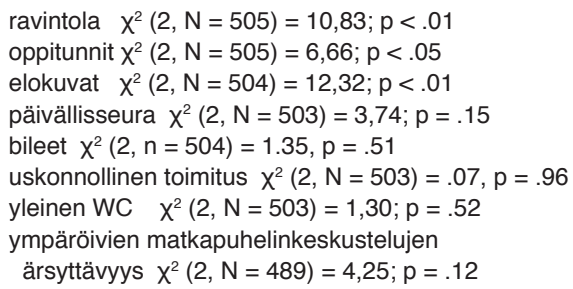

Keskustelupaikka voi vaikuttaa käytäviin keskusteluihin myös muulla tavalla. Vastaajilta kysyttiin, oliko heitä koskaan pyydetty sulkemaan puhelimensa, ja vastaus oli että kyllä oli. Tosin näin oli tapahtunut vain joka neljännelle molempina vuosina (24,5\% vuonna 2007 ja $28,7 \%$ vuonna 2010$)$, $\left.\chi^{2}(1, n=503)=1,20 ; p=.28\right)$. Nuoret aikuiset olivat lisäksi joutuneet noloihin tilanteisiin puhelimen soidessa, ja tulos oli myös tilastollisesti merkitsevä $\left(\chi^{2}(2, n=500)=7,64 ; \mathrm{p}<.05\right)$. Keskustelupaikalla oli vaikutusta keskustelun aiheisiin. Vuonna 2007 tutkitun aineiston nuorista aikuisista $94 \%$ myönsi 
tämän, ja vuonna 2010 vastaava luku oli $96.9 \%$. Ero tuloksissa oli myös tilastollisesti merkitsevä $\left(\chi^{2}(1, n=502)=5,19 ; \mathrm{p}<.05\right)$.

Noin $67 \%$ vuoden 2007 vastaajista ja $68 \%$ vuoden 2010 vastaajista totesi välttävänsä tiettyjä aiheita, kun taas loput $33 \%$ vuonna 2007 ja $32 \%$ vuonna 2010 ilmoitti, ettei matkapuhelinkeskusteluissa ole vältettäviä aiheita. $\mathrm{Ne}$, jotka välttelivät joitakin keskustelun aiheita, tekivät sen esimerkiksi puhuessaan seksistä, muista ihmissuhteista tai terveydestä vuonna 2010 enemmän kuin vuonna 2007. Erot valinnoissa eivät kuitenkaan olleet tilastollisesti merkitseviä $\left(\chi^{2}(1, n=501)=.89 ; \mathrm{p}=.35\right)$. Myöskään sukupuoli ei erotellut tehtyjä valintoja. Aiheita välteltiin siten, että alle $20 \%$ vuonna 2007 ja $20 \%$ vuonna 2010 arveli vaihtavansa puheenaihetta kesken keskustelun. Tulos ei ollut tilastollisesti merkitsevä $\left(\chi^{2}(1, \mathrm{~N}=329)=.34 ; \mathrm{p}=.56\right)$.

Lähes kaikki vastaajista, jotka ilmoittivat välteltäviä aiheita olevan, sekä kertoivat vuonna 2007 (86.8 \%) ja vuonna 2010 (89 \%) keskustelukumppanilleen jatkavansa aiheesta myöhemmin $\left(\chi^{2}(1, n=329)=.42 ; \mathrm{p}=.52\right)$. Hyvin usein myös siirryttiin rauhallisempaan paikkaan puhelimen soidessa $(\mathrm{M}=3,7$; $\mathrm{SD}=0,43$ vuonna 2007 ja $\mathrm{M}=3,6 ; \mathrm{SD}=0,52$ vuonna 2010 , kun vaihtoehtoina oli väittämässä "Siirryn rauhallisempaan paikkaan" en koskaan $=1 \mathrm{ja}$ $5=$ aina)

\section{Kuunteleminen}

Kuuntelemisen ilmenemistä selvitettiin kysymällä vastaajien halukkuutta puhua keskustelukumppaninsa kanssa mieluummin kasvokkain kuin matkapuhelimitse (vastausvaihtoehtona oli myös ei-merkitystä tai en osaa sanoa). Kuten taulukosta 3 havaitaan, vuonna 2010 valittiin enemmän kuin vuonna 2007 vaihtoehto "kasvokkain", ja ero aiempaan oli myös tilastollisesti merkitsevä $\left(\chi^{2}(3, N=503)=8,75 ; p<.05\right)$. Kyseinen muutos tapahtui sekä naisilla että miehillä samaan suuntaan. Kiintoisa tulos syntyi myös kysyttäessä, olivatko puhelinkeskustelut helpompia kuuntelemisen kannalta kuin kuunteleminen yleensä keskusteluissa, johon useimmiten vastattiin joko ei (71,8\% vuonna 2007 ja $68,9 \%$ vuonna 2010$)$ tai että vastaajat eivät osanneet sanoa, oliko tilanne tuo $(26,4 \%$ vuonna 2007 ja 26,3 \% vuonna 2010$)\left(\chi^{2}(2, N=505)=3,25 ; p=.20\right)$.

Kuuntelemisen ilmenemistä selvitettäessä haluttiin myös tietää, mihin keskustelijat kiinnittävät huomiota ja mihin he suuntaavat tarkkaavaisuutensa puhuessaan matkapuhelimessa. Kysyttäessä tarkkailevatko vastaajat matkapuhelimessaan keskustelukumppaninsa sanoja vai äänensävyjä yrittäessään keskittyä soiton tarkoituksen selvittämiseen kävi ilmi, että molempina vuosina kuunneltiin eniten kokonaisuutta, joskin vuonna 2010 eriteltiin hiukan enemmän sanoja ja äänensävyjä kuin vuonna 2007. Erot eivät ole suuria eivätkä tilastollisesti merkitseviä (taulukko 3) $\left(\chi^{2}(4, \mathrm{~N}=501)=2,23 ; \mathrm{p}=.69\right)$. Miehet kiinnittivät kuitenkin huomiota sanoihin enemmän kuin naiset molempina vuosina (naiset 
$24,4 \%$ ja miehet $25,3 \%$ vuonna 2007 , ja naiset $23,2 \%$ ja miehet $30 \%$ vuonna 2010).

Taulukko 3. Huomion kiinnittyminen ja keskittyminen matkapuhelinkeskusteluissa sukupuolen mukaan

\begin{tabular}{|c|c|c|c|c|c|c|c|c|c|c|c|c|}
\hline \multirow[b]{3}{*}{$\begin{array}{l}\text { Puhelu vai } \\
\text { kasvokkain }\end{array}$} & \multicolumn{6}{|c|}{2007} & \multicolumn{6}{|c|}{2010} \\
\hline & \multicolumn{2}{|c|}{ Vastaajat } & \multicolumn{2}{|c|}{ Naiset } & \multicolumn{2}{|c|}{ Miehet } & \multicolumn{2}{|c|}{ Vastaajat } & \multicolumn{2}{|c|}{ Naiset } & \multicolumn{2}{|c|}{ Miehet } \\
\hline & $n$ & $\%$ & $n$ & $\%$ & $n$ & $\%$ & $n$ & $\%$ & $n$ & $\%$ & $n$ & $\%$ \\
\hline kasvokkain & 164 & 77,3 & 102 & 77,9 & 62 & 78,5 & 243 & 85 & 145 & 88,4 & 98 & 80,3 \\
\hline $\begin{array}{l}\text { matkapuhe- } \\
\text { limessa }\end{array}$ & 1 & 0,5 & 0 & 0 & 1 & 1,3 & 5 & 1,7 & 2 & 1,2 & 3 & 2,5 \\
\hline ei merkitystä & 30 & 14,8 & 20 & 15,3 & 10 & 12,7 & 23 & 8,0 & 9 & 5,5 & 14 & 11,5 \\
\hline ei osaa sanoa & 15 & 7,4 & 9 & 6,9 & 6 & 7,6 & 15 & 5,2 & 8 & 4,9 & 7 & 5,7 \\
\hline $\begin{array}{l}\text { Mihin huomio } \\
\text { kiinnittyy }\end{array}$ & $n$ & $\%$ & $n$ & $\%$ & $n$ & $\%$ & $n$ & $\%$ & $n$ & $\%$ & $n$ & $\%$ \\
\hline sanat & 52 & 24,1 & 32 & 24,4 & 20 & 25,3 & 74 & 25,6 & 38 & 23,2 & 36 & 30 \\
\hline äänensävy & 8 & 3,7 & 5 & 3,8 & 3 & 3,8 & 13 & 4,5 & 9 & 5,5 & 4 & 3,3 \\
\hline yhdistelmä & 145 & 69,4 & 92 & 70,2 & 53 & 67,1 & 191 & 66,4 & 114 & 69,5 & 77 & 64,2 \\
\hline joku $n$ & 5 & 2,8 & 2 & 1,5 & 3 & 3,8 & 6 & 2,0 & 3 & 1,8 & 3 & 2,5 \\
\hline & M & SD & $\mathbf{M}$ & SD & M & SD & M & SD & M & SD & M & SD \\
\hline $\begin{array}{l}\text { läheiset } \\
\text { keskustelut } \\
\text { häiritsevät }\end{array}$ & 2,48 & 0,92 & 2,46 & 0,84 & 2,00 & 0,99 & 2,50 & 0,89 & 2,64 & 0,85 & 2,29 & 0,9 \\
\hline $\begin{array}{l}\text { tietoisuus } \\
\text { ympäröivistä } \\
\text { inmisistä }\end{array}$ & 3,95 & 0,81 & 3,89 & 0,82 & 4,05 & 0,78 & 3,94 & 0,74 & 3,88 & 0,71 & 4,0 & 0,7 \\
\hline $\begin{array}{l}\text { ympäröivien } \\
\text { keskustelujen } \\
\text { kuunteleminen }\end{array}$ & 3,07 & 0,87 & 3,07 & 0,81 & 3,05 & 0,95 & 3,09 & 0,93 & 3,20 & 1,0 & 2,95 & 0,8 \\
\hline $\begin{array}{l}\text { ympäröivien } \\
\text { keskustelujen } \\
\text { ärsyttävyys }\end{array}$ & 1,49 & 0,74 & 1,47 & 0,75 & 1,51 & 0,73 & 1,47 & 0,68 & 1,57 & 0,85 & 1,34 & 0,5 \\
\hline
\end{tabular}

puhelu/kasvokkain $\chi^{2}(3, N=503)=8,75 ; p<.05$

huomion kiinnittyminen $X^{2}(4, N=501)=2,23 ; p=.69$

ympärillä käytävät keskustelut häiritsevät,

kun itse puhuu matkapuhelimeen $\chi^{2}(4, N=444)=2,22 ; p=.69$

tietoisuus ympäröivistä inmisistä $\chi^{2}(4, N=497)=5,98 ; p=.20$

ympäröivien matkapuhelin-

keskustelujen kuunteleminen $\chi^{2}(4, N=505)=4,84 ; p=.30$

ympäröivien matkapuhelin-

keskustelujen ärsyttävyys $\chi^{2}(2, N=489)=4,25 ; p=.12$

Kuuntelemiseen oleellisesti liittyvää keskittymistä ja läsnäolon osoittamista kartoitettiin kysymyksillä siitä, miten häiritsevinä oman puhelun ympärillä käytävät muut keskustelut koetaan ja miten paljon puhuja kuuntelee muita matkapuhelinkeskusteluja. Oman matkapuhelun ympärillä käytävät muut keskustelut 
eivät juuri häiritse puhelimessa puhujaa (asteikkona $1=$ ei lainkaan, $5=$ hyvin paljon) $(\mathrm{M}=2.48$ vuonna 2007 ja $\mathrm{M}=2.50$ vuonna 2010). Keskustelut näyttävät häiritsevän naisia kuitenkin hiukan enemmän kuin miehiä (naiset $\mathrm{M}=2,46$ ja miehet $\mathrm{M}=2,00$ vuonna 2007 , ja naiset $\mathrm{M}=2,64$ ja miehet $\mathrm{M}=2,29$ vuonna 2010). Ympärillä käytäviä matkapuhelinkeskusteluja ei myöskään ilmoitettu kuunneltavan, kun vaihtoehtoina olivat 6 -portaisen Likert-asteikon mukaan "ei koskaan kuuntele" - ja "aina kuuntelee" -vaihtoehdot. Tulosten perusteella näyttää siltä, että ympärillä käytäviä matkapuhelinkeskusteluja ilmoitettiin kuunneltavan molempina vuosina vain joskus ( $\mathrm{M}=3,07$ vuonna 2007 ja $\mathrm{M}=3,09$ vuonna 2010).

Jos ympärillä käytäviä matkapuhelinkeskusteluja ei kuunneltu, ei niitä myöskään pidetty ärsyttävinä kumpanakaan vuotena (vaihtoehdot samantekevä $=1$, ärsyttävä $=3)$, sillä valintojen keskiarvo oli 1,49 $(\mathrm{SD}=0,74)$ vuonna 2007 ja $1,47(S D=0.68)$ vuonna $2010\left(\chi^{2}(2, N=489)=425 ; \mathrm{p}=.12\right)$

Läsnäoloa ja keskittymistä omaan puheluun haluttiin selvittää myös vastaajien käsityksillä siitä, kuinka tietoinen vastaaja oli ihmisistä ympärillään, kun hän puhui omaan matkapuhelimeensa. Viisiportaiselta Likert-asteikolta ( 1 = en koskaan, 5 = aina) oli molempina vuosina eniten valittu vaihtoehdot "joskus" tai "usein" ( $\mathrm{M}=3,95 ; \mathrm{SD}=0,81$ vuonna $2007, \mathrm{M}=3,94$; $\mathrm{SD}=0,74$ vuonna 2010$),\left(\chi^{2}(4, \mathrm{~N}=497)=5,98 ; \mathrm{p}=.20\right)$. Naisten ja miesten toiminta oli tässä hyvin samanlaista $\left(2007\left(\chi^{2}(3, \mathrm{~N}=210)=2,08 ; \mathrm{p}=.56\right) ; 2010\right.$ $\left(\chi^{2}(4, N=287)=5,48 ; p=.24\right)$.

\section{Pohdinta}

Tutkimuksen tavoitteena oli kartoittaa nuorten aikuisten matkapuhelinkeskusteluja yksityisyyden viestinnällisen säätelyn ja kuuntelemisen näkökulmasta sellaisena kuin se heidän käsityksensä mukaan ilmenee. Tutkimus toteutettiin samalla kyselylomakkeella samalle kohderyhmälle, joskin eri henkilöille, kolmen vuoden välein.

Matkapuhelinta käytetään edelleen jatkuvasti, se on aina mukana, siihen puhutaan paljon ja sillä ollaan yhteydessä samalla tavalla vuonna 2010 kuin vuonna 2007. Tulokset ovat varsin pysyviä ja sukupuolten väliset erot ovat hyvin marginaalisia: 1 . naisten mielestä oli hiukan enemmän sopimatonta käydä matkapuhelinkeskusteluja, kun ollaan ystävien kanssa päivällisseurueessa ravintolassa, 2. vuonna 2010 miehille sopi aiempaa enemmän puhua matkapuhelimeen bileissä kuin naisille, 3. miehet kiinnittivät kuunnellessaan hiukan enemmän huomiota sanoihin molempina vuosina kuin naiset ja 4. naiset häiriintyivät molempina vuosina oman puhelun ympärillä käytävistä keskusteluista hiukan enemmän kuin miehet. Varsin selvää oli, että edelleenkään matkapuhelimiin ei ole sopivaa puhua elokuvissa, teatterissa tai uskonnollisessa toimituksessa. Aiempaa selvemmin erottui sopimattomaksi käydä puhelinkeskusteluja 
oppituntien aikana. Mainitut puhumisen ympäristöt asettavat itsessään rajoituksia puheenaiheille, koska puhelinkeskustelujakaan ei niissä hyväksytty. Näin Petronion (2002) yksityisistä asioista kertomisen säännöt rakentuvat osaltaan automaattisesti.

Vastaajajoukosta oli kuitenkin hahmotettavissa myös eroja. Lähes kaikkiin puhelinkeskustelulle sopivaa tai epäsopivaa paikkaa tai tilannetta selvittäviin vaihtoehtoihin vastattiin, että se riippuu tilanteesta. Vuonna 2010 näytti olevan enemmän sopimatonta käydä puhelinkeskusteluja esimerkiksi vietettäessä aikaa ystävien kanssa päivällisillä. Samoin ravintolassa käytävät puhelinkeskustelut olivat aiempaa enemmän epäsopivia. Gergenin (2002) läsnäolematon läsnäolo ei ehkä nykyisin riitä: kun ollaan fyysisesti viestintäsuhteessa ystävien kanssa, ei siihen ehkä haluta mukaan teknisesti hoidettavia muita viestintäsuhteita.

Kiintoisa havainto on myös se, että julkinen WC nähtiin aiempaa enemmän joko sopivana tai tilanteesta riippuen sopivana paikkana matkapuhelinkeskusteluille. Kyseinen tila on yleensä rajattu, ja se saattaa näin olla nuorten aikuisten mielestä jopa fyysisesti riittävän suljettu ja henkilökohtainen tila Petronio ym. (2004) mukaisen suojauksen yksityisistä asioista kertomiseen.

Suurin osa vastaajista molempina vuosina oli sitä mieltä, että keskustelemisen paikka vaikuttaa keskustelun aiheisiin. Sen sijaan vältettävistä aiheista kysyttäessä noin 30 prosenttia vastaajista molempina vuosina ilmoitti, ettei sellaisia ole. Ne, jotka totesivat vältettäviä aiheita olevan, ilmoittivat aiheiden liittyvän lähinnä seksiin. Myös ihmissuhteista ei mielellään julkisesti keskusteltu, eivätkä miespuoliset nuoret aikuiset kovin runsaasti keskustelleet arvosanoista tai rahasta. Mainitut aiheet ovat sellaisia, joissa oma toiminta voi saada kyseenalaisiakin piirteitä, joten miesten näistä aiheista puhumattomuus vahvistaa Woodin (2002) havaintoja.

Asioidensa kertomista voi säädellä eri tavoin. Matkapuhelinkeskusteluissa säätely voi olla varsin mekaanista ja tilanteiden ohjaamaa. Tilanne voi olla esimerkiksi aiemmin esillä ollut teatteri tai elokuvat, jossa itse tilanne säätelee keskustelun epäsopivaksi ja estää siten myös yksityisistä asioista kertomisen. Mikäli vältettävistä aiheista tuli tutkitussa joukossa keskustelua, niistä keskustelemista säädeltiin Petronion (2002) strategioiden mukaisesti joko ilmoittamalla keskustelukumppanille, ettei puhuja juuri kyseisellä hetkellä puhua aiheista, ilmoittamalla, että puhuja palaa asiaan/soittaa myöhemmin tai vaihtamalla aihetta. Eniten käytössä oli vaihtoehto rauhallisempaan paikkaan siirtyminen molempina vuosina.

Näyttää siltä, että nuoret aikuiset rakentavat itselleen ja toisilleen tietynlaisen jatkumon asioistaan keskustelemiseen matkapuhelimilla. Mikäli kyse on sosiaalisesti tiukasta yhteydestä ja keskustelemisen ympäristöstä, kuten ystävyydestä päivällispöydässä, on aiempaa enemmän sopimatonta vetäytyä fyysisesti läsnä olemattomaan läsnäolosuhteeseen matkapuhelinkeskustelukumppanin kanssa. Sen sijaan bileissä, ainakin miesten mielestä, läsnäolemattomat 
läsnäolot sopivat viestintäsuhteisiin, ja julkinen WC tulkitaan rajatuksi paikaksi, jossa voi olla matkapuhelinkeskustelusuhteissa helpommin kuin muissa mainituissa paikoissa.

Kuvattu toiminta sopii hyvin myös suomalaiseen viestintäkulttuuriin, jonka yhtenä piirteenä on yksityisyyden kunnioittaminen (vrt. Wilkins \& Isotalus 2009, 3). Omaa yksityisyyttä suojeltiin siten, että keskustelun aiheet olivat kiinni keskustelemisen paikasta, ja jos paikkaa ei voinut vaihtaa, ilmoitettiin aiheeseen palattavan myöhemmin. Toisten yksityisyyttä puolestaan vahvistettiin sillä, että muita matkapuhelinkeskusteluja ei liiemmin ilmoitettu kuunneltavan.

Myös toinen suomalaiseen viestintäkulttuurin liittyvä piirre, kuuntelemisen tehtävän arvostus (vrt. Välikoski ym. 2008), näkyi vastauksissa selkeästi. Kuunteleminen koettiin vaikeaksi ja keskusteluja käytäisiin ennemmin kasvokkain kuin puhelimitse, mikäli olisi mahdollista. Tulos on eräällä tavalla yllätys, sillä nuorilla aikuisilla oli ollut matkapuhelin hyvin pitkään. Suurimmalla osalla puhelin oli ollut lähes puolet ikävuosistaan, joten heille matkapuhelintekniikka oli arkea ja matkapuhelin tavallinen väline yhteydenpidossa.

Samaan kuuntelemisen tärkeäksi koettuun ilmiöön viittaisi tutkimustieto siitä, että vastaajat ilmoittivat pystyvänsä keskittymään omaan matkapuhelinkeskusteluunsa eivätkä ympärillä käytävät keskustelut häirinneet suurinta osaa vastaajista kumpanakaan vuonna. Tosin naisia oman matkapuhelun ympärillä käytävät keskustelut häiritsivät hiukan enemmän kuin miehiä. Myöskään muita matkapuhelinkeskusteluja ei juuri kuunneltu. Tulos ympärillä käytävien keskustelujen häiritsemättömyydestä poikkeaa selvästi Rainie \& Keeterin (2006) yhdysvaltalaisesta tutkimustuloksesta, jossa $82 \%$ vastaajista ilmoitti kiusaantuneensa ainakin joskus joutuessaan kuuntelemaan toisten matkapuhelinkeskusteluja.

Keskittyminen omaan matkapuheluun viittaisi myös läsnäoloon oman matkapuhelinkeskustelukumppanin kanssa ja se voisi osaltaan vahvistaa sosiaalista sidettä keskustelukumppaneiden välillä, kuten Kim ym. (2007) ovat todenneet. Kyseistä toimintaa ulkopuolelta tarkasteltaessa Gergenin (2002) käsite läsnäolematon läsnäolo toteutuisi. Tätä johtopäätöstä kuitenkin heikentää se tieto, että vastaajat ilmoittivat olevansa hyvin tietoisia oman matkapuhelinkeskustelunsa ympärillä olevista henkilöistä, joten kyseinen tila ei ehkä kuitenkaan toteutuisi vahvimmillaan tässä vastaajajoukossa.

Keskittymistä ja läsnäoloa puhelinkeskusteluihin kuvaa myös se tieto, että autolla ajaessa ei juurikaan puhuttu puhelimeen. Asialle on tosin muitakin mahdollisia selityksiä, ensinnäkään opiskelijalla ei välttämättä ole autoa ja toiseksi lainsäädäntö kieltää autolla ajettaessa matkapuhelimeen puhumisen ilman hands free -laitetta. Läsnäoloa oman puhekumppanin kanssa tosin saattoi heikentää huomion kiinnittäminen ympärillä oleviin ihmisiin matkapuhelimeen puhuttaessa, minkä myönsivät lähes kaikki vastaajat tekevänsä molempina vuosina. Kyseinen tulos sopii kuitenkin hyvin yhteen sen suomalaiseen viestintäkulttuu- 
riin kuuluvan piirteen kanssa, että viestijä on huolissaan omasta viestijäkuvastaan (vrt. Wilkins \& Isotalus 2009).

Kuunteleminen voi olla kokonaisvaltaista tai erittelevää. Nuoret aikuiset vaikuttavat kuuntelevan kokonaisuutta, sillä he eivät kertoneet tarkkailevansa erityisesti puhujan äänen sävyä tai sanoja. Tosin vuonna 2010 vastaajajoukko ilmoitti enemmän erittelevänsä kuuntelemistaan, ja erityisesti miehet kuuntelivat sanoja hiukan enemmän kuin äänensävyjä. Vaikka tulos on lähinnä suuntaa-antava, se sopii hyvin aiempiin sukupuolen ja kuuntelemisen yhteydestä saatuihin tutkmustuloksiin (Imhof 2003; Schirmer \& Kotz 2002, teoksessa Waaramaa-Mäki-Kulmala 2009, 75). Samoin tulos sopii yhteen sen suomalaista viestintäkulttuuria kuvaavan piirteen kanssa, että sanallista informaatiota painotetaan (vrt. Kirra 2000).

\section{Lopuksi}

Tutkimuksessa käytettyä lomaketta oli käytetty jo tämän artikkelin otsikkosivulla mainitussa tutkimuksessa, joten lomakkeen osioiden ja asteikkojen toimivuus oli aiemmin testattu. Strukturoitu kyselylomake kuitenkin aina rajoittaa vastaajan käsitysten todellista ilmenemistä, sillä tutkija on luonut käsitysvaihtoehtoja vastaavan ilmiömaailman valmiiksi. Yksityisyyden viestinnällinen säätely ja kuunteleminen ovat kuitenkin ilmiöinä kohtuullisesti operationaalistettavissa toimivaksi kyselylomakkeeksi, jolloin laaja aineisto saadaan tehokkaasti ja taloudellisesti kerättyä. Kysely kuitenkin rajoittui tiettyyn kohderyhmään, opiskeleviin nuoriin aikuisiin, ja selvitti heidän käsityksiään. Tulosten yleistettävyys isollakin aineistolla on siten rajoittunutta, eikä todellista kuuntelemista ja yksityisyyden viestinnällistä säätelyä voida edes tutkitussa aineistossa aukottomasti verifioida. Vastausten samanlaisuus, myös sukupuolten välillä, tosin kertoo käsitysten pysyvyydestä kahtena vuotena.

Lomakkeen alkuun sijoitetut kysymykset matkapuhelimen käytöstä yleensä saattoivat vaikuttaa yksinkertaisina alkukysymyksinä vastaamisen aktiivisuuteen, sillä puuttuvia havaintoja asteikkokysymyksissä oli vähän kummankin vuoden tutkimusaineistossa.

Kyseinen tutkimus tehtynä kolmen vuoden välein toimi hyvin. Kohderyhmän pitäminen samana ja vertailuajan lyhyenä oikeuttivat tehdyt johtopäätökset. Vertailuajan pitäminen lyhyenä johtui matkapuhelintekniikan nopeasta kehittymisestä.

Kuunteleminen on matkapuhelinkeskustelun perusta, ja keskusteluissa tapahtuu yksityisyyden viestinnällistä säätelyä. Vaikka matkapuhelinkeskustelu poikkeaa kasvokkain tapahtuvasta keskustelusta, myös siinä vahvistuvat useat kuuntelemisen ja omista asioista kertomisen elementit, jotka tukevat Petronion (2002) yksityisyyden viestinnällisen säätelyn periaatteita. Se, että väl- 
tetään tiettyjä aiheita ja siirrytään puhumaan niistä rauhallisempaan paikkaan, kertoo myös siitä, että keskustelijat yrittävät kontrolloida yksityistä tietoaan julkisessa paikassa. Katz $(2003,312)$ toteaa, että tekniikasta voi tulla itserepresentaation väline. Kyseinen oletus toteutui myös tässä tutkimuksessa: matkapuhelin ei välttämättä ole toiminnan perusta - asia ja ihmisten välinen sosiaalinen vuorovaikutus on. Näin myös osaltaan vahvistui Avramin ym. (2007) ajatus vuorovaikutuksen samanlaisesta näyttäytymisestä sekä kasvokkain että matkapuhelimitse keskusteltaessa.

Jatkotutkimuksessa olisi mielenkiintoista esimerkiksi selvittää, miten nuoren aikuisen opiskelija-aineiston käsitykset suhteutuvat vanhemman väestön tai erikulttuurisen väestön käsityksiin samoista kysymyksistä.

\section{Kirjallisuus}

Altman, I. \& Taylor, D. 1973. Social Penetration: The development of interpersonal relationships. New York: Holt, Rinehart \& Winston.

Avrahami, D., Gergle, D, Hudson, S. E. \& Kiesler, S. 2007. Improving the match between callers and receivers: A study on the effect of contextual information on cell phone interruptions. Behaviour and Information Technology, 26 (3), 247-259.

Brownell, J. 1990. Perceptions of effective listeners: A management study. The Journal of Business Communication, 27 (4), 401-415.

Brownell, J. 2002 Listening. Attitudes, principles and skills. Boston: Allyn \& Bacon.

Carbaugh, D., Berry, M. \& Nurmikari-Berry, M. 2006. Coding personhood through cultural terms and practices: Silence and quietude as a Finnish "natural way of being". Journal of Language and Social Psychology, 25, 203-220.

Castells, M. \& Himanen, P. (2002). The Information Society and the Welfare State: The Finnish Modell. New York: Oxford University Press.

Flynn, J., Välikoski, T-R. \& Grau, J. 2008. Listening in the Business Context: Reviewing the State of Research. The International Journal of Listening, 22 (2), 141-152.

Gergen, K. 2002. The challenge of absent presence. In J. E. Katz \& M.Aakhus (Eds.), Perpetual Contact: Mobile Communication, Private Talk, Public Performance. Cambridge, MA: Cambridge University Press, 227-241.

Imhof, M. 2003. The Social construction of the listener: listening behavior across situations, perceived listener status, and cultures. Communication Research Reports, 20, 369-378.

Jourard, S. 1968. Disclosing man to himself. New York: Van Nostrand.

Kacchi, D. \& Link, M. 2009. Too much information: Does the Internet dig too deep? Journal of Advertising Research, 49 (1), 74-81. 
Katz, J. 2003. Bodies, machines, and communication contexts: What is to become of us. in Katz, J.(ed). Machines that become us. New Jersey: Transaction Publishers, New Brunswick,. 311-319.

Katz, J. 2007. Mobile Media and communication: Some important questions. Communication Monographs, 74 (3), 389-394.

Kim, H., Kim, G. J., Park, H. W., \& Rice, R. E. 2007. Configurations of relationships in different media: FtF, email, instant messenger, mobile phone, and SMS. Journal of Computer-Mediated Communication, 2(4), article 3. http://jcmc.indiana.edu/vol12/issue4/kim.html. Viitattu 17.10.2008.

Kirra, K. M. 2000. Finns in interaction with non-Finns: Problematic phenomena perceived as critical incidents. Journal of Intercultural Communication. http://www.immi.se./intercultural/Issue. Viitattu 20.04.2011.

Marsnik, N. 1993. The impact of gender on communication. Journal of the International Listening Association, 32-42.

Metzger, M. 2005. Communication privacy management in electronic commerce. Paper presented to the annual meeting of the International Communication Association, San Fransisco, May.

Papini, D. \& Farmer, F. 1990. Early adolescent age and gender differences in patterns of emotional self-disclosure to parents. Adolescence, 25 (100), 959-977.

Petronio, S. 2002. Boundaries of privacy: Dialectics of disclosure. Albany, NY: SUNY Press.

Petronio, S., Sargent, J., Andea, L., Reganis, P. \& Cichocki, D. 2004. Family and friends as healthcare advocates: Dilemmas of confidentiality and privacy. Journal of Social and Personal Relationships, 21 (1), 33-52.

Petronio, S. 2007. Translational research endeavors and the practices of communication privacy management. Journal of Applied Communication, 35 (3), 218-222.

Rainie, L \& Keeter, S. 2006. Per Internet Project Data Memo. Pew/Internet \& American Life Project, Associated Press, and AOL.

Virtanen, I. 2009. Finnish supportive communication: a qualitative study on middle-aged single's support seeking. Teoksessa R.Wilkins \& P.Isotalus (eds.) 2009. Speech Culture in Finland. New York: University Press of America, 117-138.

Välikoski, T-R, Ilomäki, I., Mäki, E. \& Janusik, L. 2005. Kuunteleminen keskustelussa - yhdysvaltalaisen ja suomalaisen aineiston vertailu. Teoksessa T-R. Välikoski, E. Kostiainen, E. Kyllönen \& L. Mikkola (toim.). Prologi. puheviestinnän vuosikirja 2005. Jyväskylä: Prologos, 88-108.

Waaramaa-Mäki-Kulmala, T. 2009. Emotions in Voice. Acta Universitatis Tamperensis 1399. Tampere. Tampere University Press. 
Wilkins, R. \& Isotalus, P.(eds.) 2009. Speech Culture in Finland. New York: University Press of America.

Wilkins, R. \& Gareis, E. 2006. Emotion expression and the locution "I love you": A cross-cultural study. International Journal of Intercultural Relations, 30, 51-75.

Wood, J. (2002). Gendered lives. Communication, gender and culture. Canada:Wadsworth Group. 